\title{
On Cultural Connotations of Death Euphemisms in English and Chinese: A Case Study of The Story of the Stone and Its Translation by Hawkes
}

\author{
Jialin Xu \\ Department of Liberal Arts and Law, Guangling College, Yangzhou University, Yangzhou, China \\ Email address: \\ 3208963014@qq.com \\ To cite this article: \\ Jialin Xu. On Cultural Connotations of Death Euphemisms in English and Chinese: A Case Study of The Story of the Stone and Its \\ Translation by Hawkes. International Journal of Language and Linguistics. Vol. 9, No. 1, 2021, pp. 17-23. \\ doi: $10.11648 /$ j.ijl1.20210901.13
}

Received: February 2, 2021; Accepted: February 9, 2021; Published: March 4, 2021

\begin{abstract}
Euphemism, as a language phenomenon, exists in both English and Chinese language. At the same time, euphemism is also a cultural phenomenon. Different habits of using euphemisms form gradually through different cultural traditions, values and national personalities. Generally speaking, euphemism is an effective and simple way for people to communicate and convey their emotions. It is generally recognized that The Story of the Stone is the highest achievement of Chinese classical novels, especially in Chinese traditional culture. In many different languages and cultures, death is one of the taboo subjects. The Story of the Stone contains a large number of euphemisms, including more than 100 death euphemisms. By taking The Story of the Stone and its translation by Hawkes as the research objects, this thesis looks into the similarities and differences of the cultural connotations in Chinese and English death euphemisms via quantitative analysis of their classifications and distributions. Specifically, there exist differences in religious beliefs and hierarchical concepts between Chinese and English cultures, as well as the similarities in cognitive attitudes and physical reactions between two sides. Hence, some relevant translation strategies are put forward by analyzing the cultural contrasts reflected by these Chinese and English euphemisms, which will accordingly guarantee a successful cross-cultural communication.
\end{abstract}

Keywords: The Story of the Stone, Death Euphemisms, Contrastive Analysis of Culture, Chinese and English

\section{Background}

According to Wang [12], euphemism is a unique language style that enables both parties to achieve the ideal purpose of commmunication. And to some extent, euphemism can raise human civilization to a higner level.

The Story of the Stone is not only one of the most accomplished classical masterpieces in China, but also a bright pearl in the treasure house of Chinese traditional culture. Cao Xueqin uses a variety of figures of speech and euphemisms, which contains the rich traditions of Chinese culture. There are lots of translations of The Story of the Stone, among which the one by David Hawkes is widely accepted and well received by the readers. Wang [13] pointed out that a lot of euphemisms containing Chinese culture could bring obstacles to cultural translation and would be a great challenge for translators. $\mathrm{Li}$ [10] concluded that the translation by Hawkes paid more attention on the cultural meaning of the original text, in order to make it easier for western readers to understand. Hawkes used more free transaltion methods, so the translation was more flexible and creative. He and Long [3] summarized the lexical characteristics of death euphemisms, including ambiguity, substitution, trope, analogy, and circumlocution.

The Story of the Stone is abundant in euphemisms, especially death euphemisms. The thesis will probe into the cultural differences and similarities reflected by death euphemisms, and will dedicate to promoting the progress of cross-cultural exchanges effectively by providing corresponding strategies.

Therefore, the studies of death euphemisms in The Story of the Stone can promote the communication between different countries and have a major influence on cross-cultural communication. 


\section{A Brief Introduction to Euphemism}

Language is the carrier of culture. Euphemism, a common language phenomenon, usually contains much culture information, such as religious faith, ethics, customs, values and so forth. Euphemism appears in a certain social context and is restricted by the environment, so it is a common cultural phenomenon in the process of language use. Death is a taboo subject, because it seems offensive or embarrassing. When people talk about the death, they often use a euphemism instead. For example, 'pass away 'is a euphemism for 'die'.

In China, the euphemism existed for centuries. From $156 \mathrm{BC}$ to $87 \mathrm{BC}$, Emperor Wu of the Han Dynasty adopted Confucianism as the orthodox national ideology and abolished other schools of thought. People had to be careful with their words and behaviors to escape being punished and even persecuted. At that time, the euphemism developed and prevailed in China's feudal society.

English euphemism could go back to the Norman Conquest in 1066. Normans and the native English upper class used "elegant" Latin words instead of some Anglo-Saxon words which were considered rude and uncouth. Hence, these Latin words were gradually absorbed into the English language and were regarded as the earliest English euphemisms.

\subsection{Definitions and Functions of Euphemism}

Chen Wangdao, a renowned educator, was one of the scholars in China who provided explicit definition of euphemism. In his book An Introduction to Rhetoric, the euphemism was termed “婉曲辞” [6], which was to say something with an implicit expression, and could make you think of qualities and ideas beyond its basic meanings. Furthermore, he maintained that people often substituted taboo words which were not accepted as socially correct with pleasant expressions. It is noted that the earliest literal application of the euphemism could be dated back to Shijing 'Book of Poetry'. While modern Chinese scholars, represented by Chen Wangdao, studied euphemisms from the perspective of rhetoric in the way that they extended the concept of the euphemism at the word level to the sentence level and even the text level.

The English word "euphemism" was derived from the Greek. "eu" meant "sounding good" or "well" and "pheme" meant "saying" or "speech", Thus the word denoted "to speak with good words or in a pleasant manner". Judith and Carole pointed out that euphemism was usually to replace a clearer and more offensive word with a harmless or pleasant expression [4]. Later, definitions of euphemism became more and more precise. Some people regarded the euphemism as a rhetoric approach. Allan and Burridge defined the euphemism as a communication strategy which avoided offending other people with the connoting or substituting controversial expression [1].

Although scholars at home and abroad have some differences in the definition of the euphemism, the purpose of using euphemisms is to avoid saying unpleasant words. Euphemism performs three main functions, including avoiding taboo, politeness and dissembling. In general, the euphemism is a polite word or phrase that is used to refer to things which people may find shocking, embarrassing or upsetting to talk about.

\subsection{Death Euphemisms}

There is no doubt that death is the ultimate destination of life and it is both cruel and inevitable. The fear of death makes people be afraid to mention death directly. The pain and blow that death brings to people also makes them be reluctant to talk about it. Therefore, death becomes a taboo subject.

In the early stage of human civilization, science and culture were not yet developed rapidly. People believed in the forces of nature and thought that spoken or written words could decide fortunes. People were frightened to say something not socially accepted because they worried that a disaster would strike.

However, death is a common physiological phenomenon in daily life. Death has to be mentioned a lot of times, for it is certain to happen and impossible to avoid. Death is not an enjoyable topic which often evokes anxiety, panic and unease among listeners and speakers. Therefore, using death euphemisms is a good choice because it can not only connote the meaning of death and ease the pain and tension of people.

The Story of the Stone is rich in death euphemisms, which will be examined and reviewed in detail in the following section.

\section{Literature Review}

Chen made a contrastive study of some typical examples of The Story of the Stone and found that there were obvious similarities and differences in religious characteristics between China and the West [7]. Zhuang compared and evaluated the translation methods of death euphemisms in two English versions of The Story of the Stone from the perspective of cultural translation theory proposed by Susan Bassnett [14], while Ren analyzed translation strategies of death euphemisms based on four English versions of The Story of the Stone [11]. Besides, Li [8] and Zeng [15] summarized death euphemisms in The Story of the Stone from cultural connotations and translation aesthetics respectively. Recently, Liu conducted a comparative analysis of death euphemisms in The Story of the Stone from a cognitive perspective, i.e., the conceptual metaphor theory and conceptual metonymy theory [9].

Although most of the previous studies focus on death euphemisms in The Story of the Stone with concrete examples, there is still a lack of explicit classification, the minute statistics based on translation cases. This will shed lights on the present study and become the topic of this thesis.

\section{Death Euphemisms in the Novel}

\subsection{An Introduction to The Story of the Stone}

The Story of the Stone is a vivid and glowing masterpiece 
of world literature. It describes the ancient feudal society of China in the 18 th century.

The first part of the story, The Golden Days, begins the tale of Jia Bao-yu, a gentle young boy who prefers girls to Confucian studies, and his two cousins. Xue Bao-chai is his parents' choice of a wife for him, and Lin Dai-yu is the ethereal beauty. With the rise and fall of four aristocratic families, Jia, Shi, Wang and Xue, as the background, The Story of the Stone is a strong rebellion against feudal society and the literary peak of praising women.

The Story of the Stone embodies the feudal social system, including marriage system, imperial system and feudal ethics Thus it is of great significance in the fields of economy, history, culture and so forth. It exposes the darkness and corruption of the daily life of officials and aristocrats, condemns orthodox Confucianism and feudal ethics.

Cao Xueqin, the author of The Story of the Stone, is a famous novelist in the Qing Dynasty. He was born into an aristocratic family in 1715 and died in Beijing in 1763. The emperor visited his family four times, which was undoubtedly a great favor to the Cao family. During the reign of Emperor Yongzheng, the Cao family was implicated in the political infighting which led to the downfall. Cao Xueqin witnessed the great changes in his family when he was young. The cruel life gave him the inspiration and source of creation.
In The Story of the Stone, Cao Xueqin described the rise and fall of an aristocratic family with his own experience.

The Story of the Stone is a successful model in classical novels, which not only attracts Chinese scholars to explore and study, but also has the research value for western countries. Many translations of The Story of the Stone were published. Among the English versions, two translations received a lot of compliments from the public. The translation of Yang Xianyi was completed by Yang Xianyi and his wife Gladys B. Tayler. The first 80 chapters of Hawkes's translation were completed by David Hawkes during 10 years, and the last 40 chapters were completed by Hawkes's son-in-law, John Minford, which marked the birth of the first complete 120 chapters of The Story of the Stone in the western world.

\subsection{Statistics of Death Euphemisms in The Story of the Stone}

The following four tables [2, 5] are death euphemisms in The Story of the Stone. Words are sorted in a table by the first letter of the first word, in the order from left to right and then from top to bottom. The number in a table represents the chapter of the novel in which the death euphemism appears. There are 103 death euphemisms in The Story of the Stone and 95 typical death euphemisms are listed in the tables below.

Table 1. One-character death euphemisms.

\begin{tabular}{|c|c|c|c|c|c|}
\hline $\begin{array}{l}\text { 殡 } 53 \\
\text { funeral } \\
\text { 亡 } 5 \\
\text { fall }\end{array}$ & $\begin{array}{l}\text { 薨 } 58 \\
\text { pass away } \\
\text { 殉 } 111 \\
\text { render a final service }\end{array}$ & $\begin{array}{l}\text { 绝 } 33 \\
\text { kill } \\
\text { 缢 } 5 \\
\text { take her own life }\end{array}$ & $\begin{array}{l}\text { 没 } 14 \\
\text { die } \\
\text { 夭 } 77 \\
\text { take a loving last leave }\end{array}$ & $\begin{array}{l}\text { 殁 } 63 \\
\text { death } \\
\text { 终 } 2 \\
\text { die }\end{array}$ & $\begin{array}{l}\text { 去 } 3 \\
\text { go }\end{array}$ \\
\hline
\end{tabular}

Table 2. Two-character death euphemisms.

\begin{tabular}{|c|c|c|c|c|}
\hline $\begin{array}{l}\text { 殡天 } 63 \\
\text { dead }\end{array}$ & $\begin{array}{l}\text { 薄命 } 4 \\
\text { bottle-gourd }\end{array}$ & $\begin{array}{l}\text { 辞世 } 13 \\
\text { gone }\end{array}$ & $\begin{array}{l}\text { 度脱 } 1 \\
\text { save a few souls }\end{array}$ & $\begin{array}{l}\text { 飞升 } 13 \\
\text { Immortality was within his grasp. }\end{array}$ \\
\hline $\begin{array}{l}\text { 焚身 } 103 \\
\text { die by her own hand }\end{array}$ & $\begin{array}{l}\text { 告殂 } 14 \\
\text { the announcement of the } \\
\text { premature demise }\end{array}$ & $\begin{array}{l}\text { 过阴 } 75 \\
\text { lost the use of your faculties }\end{array}$ & $\begin{array}{l}\text { 归西 } 46 \\
\text { go to her rest }\end{array}$ & $\begin{array}{l}\text { 薨逝 } 95 \\
\text { pass away }\end{array}$ \\
\hline $\begin{array}{l}\text { 魂归 } 98 \\
\text { suffering spirit returns to the } \\
\text { Realm of Separation }\end{array}$ & $\begin{array}{l}\text { 捐馆 } 14 \\
\text { is conveyed to his last } \\
\text { resting-place }\end{array}$ & $\begin{array}{l}\text { 溘逝 } 106 \\
\text { demise }\end{array}$ & $\begin{array}{l}\text { 没了 } 13 \\
\text { dead }\end{array}$ & $\begin{array}{l}\text { 去世 } 3 \\
\text { pass on }\end{array}$ \\
\hline $\begin{array}{l}\text { 去也 } 5 \\
\text { gone }\end{array}$ & $\begin{array}{l}\text { 去了 } 46 \\
\text { dismissed }\end{array}$ & $\begin{array}{l}\text { 气绝 } 98 \\
\text { breathe her last }\end{array}$ & $\begin{array}{l}\text { 寿终 } 110 \\
\text { end her days }\end{array}$ & $\begin{array}{l}\text { 寿夭 } 5 \\
\text { slain }\end{array}$ \\
\hline $\begin{array}{l}\text { 升仙 } 63 \\
\text { go straight to heaven }\end{array}$ & $\begin{array}{l}\text { 丧命 } 69 \\
\text { die }\end{array}$ & $\begin{array}{l}\text { 停床 } 51 \\
\text { breathe her last }\end{array}$ & $\begin{array}{l}\text { 无常 } 5 \\
\text { mortal mutability }\end{array}$ & $\begin{array}{l}\text { 亡故 } 14 \\
\text { die }\end{array}$ \\
\hline $\begin{array}{l}\text { 呜呼 } 16 \\
\text { breathe his last } \\
\text { 圆寂 } 18 \\
\text { die }\end{array}$ & $\begin{array}{l}\text { 仙逝 } 2 \\
\text { end her days } \\
\text { 夭折 } 78 \\
\text { cut off so young }\end{array}$ & $\begin{array}{l}\text { 仙去 } 109 \\
\text { become a fairy } \\
\text { 早夭 } 98 \\
\text { would not live long }\end{array}$ & $\begin{array}{l}\text { 天逝 } 16 \\
\text { premature departure } \\
\text { 自刨 } 69 \\
\text { Cutting one's throat }\end{array}$ & $\begin{array}{l}\text { 易箦 } 16 \\
\text { die }\end{array}$ \\
\hline
\end{tabular}

Table 3. Three-character death euphemisms.

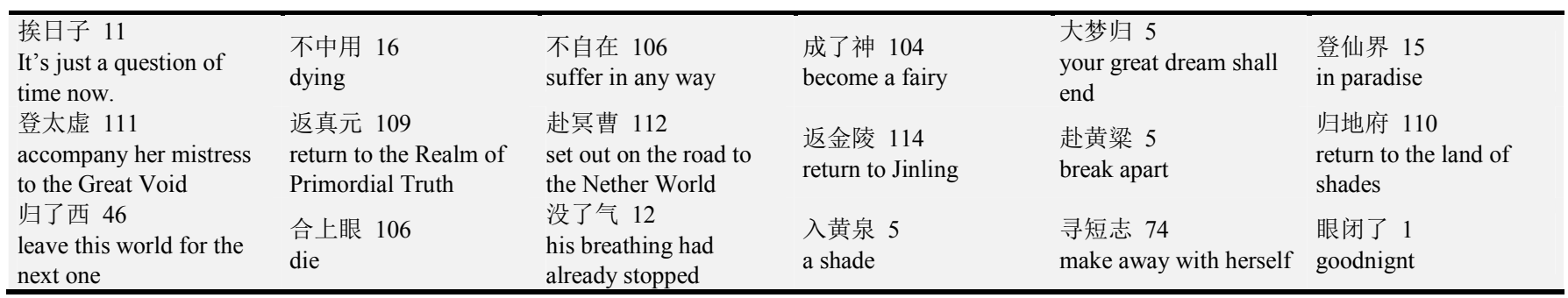


Table 4. Other death euphemisms.

\begin{tabular}{|c|c|c|c|}
\hline $\begin{array}{l}\text { 我这病便不能好了 } 69 \\
\text { This illness I am suffering from will } \\
\text { not get better. }\end{array}$ & $\begin{array}{l}\text { 闭了这眼 } 29 \\
\text { close my old eyes }\end{array}$ & $\begin{array}{l}\text { 别有大故 } 34 \\
\text { die }\end{array}$ & $\begin{array}{l}\text { 断了这口气 } 29 \\
\text { draw my last breath }\end{array}$ \\
\hline $\begin{array}{l}\text { 登了仙去 } 104 \\
\text { risen to heaven in the form of an } \\
\text { immortal }\end{array}$ & $\begin{array}{l}\text { 归西去了 } 46 \\
\text { go to her rest }\end{array}$ & $\begin{array}{l}\text { 功行圆满 } 63 \\
\text { find the secret of immortality }\end{array}$ & $\begin{array}{l}\text { 黄泉路近 } 5 \\
\text { Of death's dark frontier lay close at } \\
\text { hand. }\end{array}$ \\
\hline $\begin{array}{l}\text { 魂魄离身 } 16 \\
\text { soul had already left his body }\end{array}$ & $\begin{array}{l}\text { 荒冢一堆草没了 } 1 \\
\text { In grassy graves they lie now, every } \\
\text { one. }\end{array}$ & $\begin{array}{l}\text { 结果了他 } 33 \\
\text { finish off what I have begun and put } \\
\text { him down }\end{array}$ & $\begin{array}{l}\text { 了然去也 } 63 \\
\text { leave }\end{array}$ \\
\hline $\begin{array}{l}\text { 暝然而逝 } 16 \\
\text { slid once more into the dark }\end{array}$ & $\begin{array}{l}\text { 莫道缟仙能羽化 } 37 \\
\text { White flower-sprite, shake your } \\
\text { silken wings! Away! }\end{array}$ & $\begin{array}{l}\text { 抹了脖子 } 67 \\
\text { cut her throat }\end{array}$ & $\begin{array}{l}\text { 那里中用了呢 } 32 \\
\text { dead }\end{array}$ \\
\hline 伸腿去了 13 & 上五台山 22 & 升仙去了 63 & 尸居馀气 64 \\
\hline has been taken from us & walk ahead of the hearse & go off to heaven & was finished from that hour \\
\hline $\begin{array}{l}\text { 脱去皮囊 } 63 \\
\text { cast off the corrupt garment of flesh }\end{array}$ & $\begin{array}{l}\text { 未必謷的过年去 } \\
11 \\
\text { I don't think I am going to last the } \\
\text { year out. }\end{array}$ & $\begin{array}{l}\text { 下世的光景 } 1 \\
\text { the unmistakable symptoms of a } \\
\text { decline }\end{array}$ & $\begin{array}{l}\text { 香魂一缕随风散 } 98 \\
\text { Her fragrant soul disperses, wafted } \\
\text { on the breeze. }\end{array}$ \\
\hline $\begin{array}{l}\text { 香魂出空 } 111 \\
\text { gentle soul fled its mortal frame }\end{array}$ & $\begin{array}{l}\text { 已出苦海 } 63 \\
\text { leave this sea of misery behind him }\end{array}$ & $\begin{array}{l}\text { 奄奄一息 } 106 \\
\text { feeble }\end{array}$ & $\begin{array}{l}\text { 咽喉气绝 } 111 \\
\text { The last breath was soon strangled } \\
\text { from her throat. }\end{array}$ \\
\hline $\begin{array}{l}\text { 有个长短 } 11 \\
\text { if anything should happen to her }\end{array}$ & $\begin{array}{l}\text { 一时有个好歹 } 57 \\
\text { if anything were suddenly to happen } \\
\text { to her }\end{array}$ & $\begin{array}{l}\text { 致使香魂返故乡 } 5 \\
\text { Your soul must fly home to its own } \\
\text { country. }\end{array}$ & $\begin{array}{l}\text { 这个田地 } 11 \\
\text { really that serious }\end{array}$ \\
\hline
\end{tabular}

\subsection{An Analysis of Translation Cases}

The expressions of death euphemisms are different due to the differences in religious beliefs and social hierarchy between China and the West. Death, as a normal natural phenomenon, its characteristics of the physiological response are not much different between China and the West. In addition, there are many death euphemisms related to age and specific context in The Story of the Stone.

This paper takes The Story of the Stone as a case study, more than 100 death euphemisms as the research objects. The bibliography is referred to for further information and some representative examples $[2,5]$ are selected for analysis.

\subsubsection{Death Euphemisms about Religion}

\section{For example:}

\section{（1）于去冬圆寂了。(《红楼梦》第十八回）}

Translation: She died last winter.

The word “圆寂” in this sentence is used to describe the death of Miaoyu. “圆寂” is a typical Buddhist term which often used to refer to the death of an outstanding or learned monk. The Sanskrit translation of “圆寂” is nirvana that is the final state of complete knowledge and understanding. The Buddhism believers aim to pursue a condition of great happiness and a feeling of peace.

For example:

\section{(2) 莫道缟仙能羽化。(《红楼梦》第三十七回)}

Translation: And join with me to hymn the dying day.

“羽化” is a word with the symbol of Taoism. Originally, “羽化” referred to the progress in which insects grew wings after breaking their cocoons, such as butterflies and cicadas. Later, “羽化” was used to show the vision of people becoming immortals.

\subsubsection{Death Euphemisms About Social Status}

In the Chinese feudal society, the clan system, the rigid social hierarchy and strict rules of etiquette ran through many aspects of social life. The social structure was like a pyramid. At the top of the pyramid was the monarch, and at the bottom of the pyramid were the civilians. The concepts of hierarchy continued to permeate the society. The Story of the Stone described in the lives of feudal aristocratic families in detail. In the novel, the language of aristocrats, civilians, slaves and so forth reflected the old class system.

For example:

(3) 袭人之母业已停床。(《红楼梦》第五十一回)

Chapter 51: Aroma's mother had already breathed her last.

“停床” was an euphemism for “death”. China was a feudal society in ancient times. When people with different social status died, the language expressions were different. The status of Aroma's mother was not high, so “停床” was used to imply the meaning of her death.

For example:

(4) 谁知上回所表的那位老太妃已薨。(《红楼梦》第 五十八回)

Chapter 58: The Dowager Consort of the late Emperor whose illness we referred to in an earlier chapter had now passed away.

“薨” was originally used to refer to the sound made when the house collapsed, but later it was used to refer to the death of a noble person with an illustrious status, such as an aristocrat, a senior official or a royal family member.

\subsubsection{Death Euphemisms about Physiology}

Death itself is a natural physiological phenomenon. Therefore, in the process of the continuous development of death euphemisms, there are also some euphemisms related to physiological activities. 
For example: 回)

（5）众人上来看时，已没了气了。（《红楼梦》第十二

Chapter 12: When they examined him more closely they found that his breathing had already stopped

Wang Xi-feng set a trap for her admirer, Jia Rui. Jia Rui was ill. When spring came, Jia Rui's sickness grew worse. Although Jia Rui took lots of medicines, no medicine helped him to recover. One day, a lame Taoist who claimed to be able to cure retributory illnesses handed a mirror to Jia Rui. The Taoist asked him to look into the back of the mirror and not to look into the front. However, Jia Rui looked into the wrong side of the mirror and finally died.

For example:

（6）几时我闭了这眼，断了这口气。(《红楼梦》第二 十九回）

Chapter 29: I'll be glad when l've drawn my last breath and closed my old eyes for the last time.

Grandmother Jia heard that Bao-yu and Dai-yu were angry with each other. She said this sentence to ease the relationship between them because they were both loved very much by her.

Breathing is vital to a person's life. Stopping the breathing, stopping the heart beating, closing the eyes, and the blood heat going down are common physiological phenomena of death, wherever in China or the West.

\subsubsection{Death Euphemisms About Age}

For example:

（7）秦鲸卿天逝黄泉路。（《红楼梦》第十六回）

Chapter 16: Qin Zhong is summoned for premature departure on the Journey into Night.

The word “天逝” which implied a certain feeling of regret was used here to refer to the death of Qin Zhong. “天” means that someone dies before the natural or proper time. When a person dies when he or she is young, it is an unpleasant and extremely sad thing for a family. People are not willing to mention the death directly, because death may be unbearably cruel.

For example:

（8）史太君寿终归地府。（《红楼梦》第百一十回）

Chapter 110: Lady Jia ends her days, and returns to the land of shades.

Grandmother Jia had a long life and enjoyed her full share of happiness. She spent her twilight years and passed away peacefully. In ancient China, people usually thought that those who did many good deeds in life eventually had a good end result.

\subsubsection{Death Euphemisms About Context}

Context refers to the events, information or situation that are related to something and that help readers to understand it To appreciate what these euphemisms mean, it is necessary to look at them in context.

For example:

（9）他病人不过是这么说，那里就到得这个田地了? (《红楼梦》第十一回)

Chapter 11: It's not really that serious, sick people always say things like that.

Qin-shi suffered from a disease and Jia Bao-yu was very sad and in tears. Although Wang Xi-feng was deeply affected, she feared that it mignt make Qin-shi more distressed. The declared purpose of their visit was to cheer Qin-shi up. So Wang Xi-feng said this sentence to Jia Bao-yu.

For example:

（10）婶子, 我知道我这病不过是挨日子。（《红楼梦》 第十一回)

Chapter 11: I know that it's just a question of time now.

Wang Xi-feng told Qin-shi that they found a doctor and there was really nothing to worry about. Qin-shi smiled and said this sentence.

\section{Cultural Connotations of Death Euphemisms in English and Chinese}

\subsection{The Contrasts between Chinese Culture and English Culture}

In the late period of the matriarchal society, China entered into the farming stage from the fishing and hunting stage. For thousands of years, people have depended on and benefited from the land, which have made people be full of love for the land.

Britain is an island country with the highly developed navigation industry. The love of sailing is closely related to the love of gambling and taking risks.

\subsubsection{Different Religions}

In China, people do not have a unified religious belief. Buddhism, a religion of east and central Asia, spreads to China from India. Buddhism is based on the teaching of Gautama Buddha and it is originally a branch of Hinduism. Hinduism is the main religion in India, which includes belief in reincarnation. Reincarnation is the belief that after someone dies, their soul lives again in another body. Therefore, Buddhism believes in the reincarnation of life and death. The significance of life is to pursue the eternal happiness. After death, good people go to the Buddha pure land, and bad people are believed to be punished by being sent to hell. The final state of Buddhism, known as nirvana, is a condition of great happiness and a feeling of peace. Taoism is a way of thought developed in ancient China, emphasizing a natural and simple way of life. It is based on the writings of Lao Tzu. Taoism believes that everything in the universe evolves from “道”. It believes in the immortality of the soul. People may be carefree through spiritual growth. After learning “道”, they may have magical power, and then live for ever. Life is not the beginning, and death is not the end.

In Western culture, Christianity is the religion based on the life. Jesus Christ is worshiped by Christians as the son of God. Christians believe that people are born with sins and Jesus died on the cross for their sins. Only when they experience the trials and tribulations in the real world and make atonement for their sins by order of God, can they be liberated and their lives become eternal. A large number of 
death euphemisms in English come from the Holy Bible, other Christian legends and allusions.

\subsubsection{Different Class Systems}

Although Chinese old class system is slowly disappearing, it has a significant and profound impact on the development of death euphemisms in Chinese. In the Zhou Dynasty, the ruling class divided people into ten classes. Gradually, a very strict hierarchical system was adopted. In order to distinguish different classes, people in the same group used a specific language system. Death euphemism was a classic example. When people of different social classes died, the words about their deaths were not the same. The death of a monarch was called “驾崩”or “崩”. The death of a government officer was called “薨” or “卒”, that of a soldier was called “不禄”, and that of a civilian was called “死”. In the Tang Dynasty, new standards were set. Death euphemisms of all officers distinguished according to their own positions.

In Western countries, people thought that all men were equal. They advocated freedom and democracy and attached importance to the self-worth of people. Therefore, although there were a great number of death euphemisms in English, they did not distinguish between the upper class and lower class. In medieval West, whether aristocrats or serfs, their funerals were simple. The hierarchy about death was not very rigid, so the social class system was not much reflected in the language.

\subsection{The Similarities Between Chinese Culture and English Culture}

A lot of descriptions of deaths in The Story of the Stone show that Chinese and Western people have similar characteristics in their attitudes towards death. Specifically, people may be deeply upset and sad when their relatives or friends pass away.

Some death euphemisms about physiology are listed above. They indicate that Chinese and Western people have similar physical reactions about death.

\subsubsection{Similar Attitudes to Death}

Life is often compared to a one-way ticket, eventually destined for the end of the life. Death is the final destination of life. Because of this commonality, it is normal that Chinese and Western countries have roughly similar attitudes towards death.

In the chapter 3 of The Story of the Stone, when people talked about the illness and death of Lin Dai-yu's mother, Grandmother Jia felt sad and burst into tears.

In English, "go" and "depart" are equivalent to the Chinese words “走了，去，归,回”. This indicates that English and Chinese have almost the same opinions and feelings about death. The death of a relative or friend is often a tremendous shock to a person. Death may precipitate people into great pain and grief. Therefore, people are not willing to mention death directly. Instead, they use the death euphemisms in order to ease the pain and grief.

\subsubsection{Similar Physical Features}

Two obvious signs of human death are that the heart stops beating and breathing stops. In the description of the physical characteristics of death, there is few significant differences between English and Chinese.

In the chapter 67 of The Story of the Stone, Wang Xi-feng found that her husband had married a concubine without her knowledge and Joker told her the whole story of Liu Xiang-lian. There was an euphemism “抹了脖子” in the text of the novel. Hawkes adopted a euphemistic expression and translated it as "cut her throat".

\subsection{Implications for Cross-cultural Communication}

Although Chinese and Western religious beliefs are different, Chinese death euphemisms related to Buddhism and Taoism may often have corresponding English concepts in Christianity. For example, "heaven, paradise, immortal, fairy” may be used to translate “升仙, 登仙界, 登了仙去, 成了神”。

In ancient China, the religious and moral values were affected by the pagoda-like national political system and patriarchal clan system. Chinese hierarchical organization exerted a powerful influence on the formation of the death euphemism. However, there are not noticeable class differences in English death euphemisms. In China, “停床” refers to the death of the lower class and “薨逝” refers to the death of the upper class. But in English, these two words both may be translated as "breathe one's last" or "pass away".

Death euphemisms about context reflect that Chinese and Western people have similar attitudes towards death. This kind of death euphemisms may be translated as "death" directly, also they may be substituted with implicit expressions. For example, “那里中用了呢” could be translated as “dead", and “有个长短” could be translated as "if anything should happen to her".

Most death euphemisms about physiology could be translated according to their literal meaning because Chinese and Western people have common physical features of death. For example, “抹了脖子” was translated as “cut her throat”. But there are comparatively few euphemisms which are given the general meaning in a more natural way. In The Story of the Stone, Hawkes translated “伸腿去了” as “has been taken from us".

To sum up, if the implicit meaning may be retained in the translation and is helpful for readers of the target language to accept, then the translator can adopt the literal translation method. If it is translated directly, the implied meaning of the original text may not be clearly expressed, which means that it is necessary to take the context of the sentence into account and express the meaning of the original text as much as possible using the free translation method. If a death euphemism has an exact corresponding expression in the target language, it can be used to translate directly.

\section{Conclusion}

Euphemisms can reflect the nationality and commonality of different cultures. This paper conducts some statistical 
analysis of the death euphemisms in The Story of the Stone. There are five death euphemisms classifications in the novel, including euphemisms about religion, social status, physiology, age and context. These euphemisms reveal the differences in religious beliefs and hierarchical structures between Chinese and English cultures, as well as the similarities in cognitive attitudes and physical reactions between the two sides. Through the contrastive textual analysis of The Story of the Stone and its translation by Hawkes, it is acknowledged that euphemistic meaning may be lost in the process of euphemism translation mainly due to the cultural differences or mismatches between Chinese and English language. This means the translation of death euphemisms should not only convey the literal meaning of the original text, but also take the cultural meaning of the original text into account. Thus a successful cross-cultural communication be achieved.

\section{References}

[1] Allan, K. and Burridge, K. (1991), Euphemism and Dysphemism, Oxford: Oxford University Press.

[2] Hawkes, D. and Minford, J. (1986), The Story of the Stone, London: Penguin Classics.

[3] He Peiyi, Long Lu (2020), An Analysis of the Linguistic Features and Cultural Connotations of English Euphemisms (in Chinese), Overseas English (24): 119-121.

[4] Judith, S. and Carole, G. (1983), Kind Words: A Thesaurus of Euphemism, Oxford: Oxford University Press.

[5] Cao Xueqin, Gao E (2001), The Story of the Stone (in Chinese), Changsha: Yuelu Press.

[6] Chen Wangdao (1932), An Introduction to Rhetoric (in Chinese), Shanghai: Dajiang Book Shop.
[7] Chen Tian, Sun Guiping (2005), The Euphemism of "Death" in the Chinese and English Versions of The Story of the Stone (in Chinese), Journal of Jiangsu Normal University (Philosophy and Social Sciences Edition) (4): 69-72.

[8] Li Kun (2010), Death Euphemism and its English Translation in The Story of the Stone (in Chinese), Journal of Hebei Polytechnic University (Social Science Edition) (4): 135-137.

[9] Liu Ren (2015), Cognitive Study of Death Euphemism in The Story of the Stone (in Chinese), Master's thesis, Changsha: Hunan Normal University.

[10] Li Xiao (2019), A Contrastive Study on the Catalogue Translation of Two English Versions of The Story of the Stone (in Chinese), Overseas English (6): 37-38, 58.

[11] Ren Xiankai, Ke Xinli (2011), On the Translation Strategies of Euphemism in four English versions of The Story of the Stone: A Case Study of Death Euphemism (in Chinese), $A$ Dream of Red Mansions (6): 73-85.

[12] Wang Baoying (2019), A Contrastive Study of English and Chinese Euphemism: A Case Study of euphemisms of the translation of The Story of the Stone (in Chinese), English On Campus (45): 216-217.

[13] Wang Yunxia (2020), A Contrastive Study on Non-literal Expressions in English Versions of Hong Lou Meng (in Chinese), Master's thesis, Xian Yang: Northwest A \& F University.

[14] Zhuang Guowei (2008), Cultural Comparison of Death Euphemism Translation in Two English Versions of The Story of the Stone (in Chinese), Journal of Yancheng Normal University (Humanities and Social Sciences Edition) (2): 87-90.

[15] Zeng Lijie (2019), A Study on the English Translation of Death Euphemism in The Story of the Stone from the Perspective of Translation Aesthetics (in Chinese), Master's thesis, Quanzhou: Huaqiao University. 